\title{
IMPLEMENTASI ASAS PROPORSIONALITAS DALAM PERJANJIAN TERA- PAUTIK DALAM RANGKA MEWUJUDKAN KEADILAN BAGI PASIEN
}

\author{
Alfis Setyawan \\ Fakultas Hukum Universitas Internasional Batam \\ Jl. Gajah Mada, Baloi - Sei Ladi, Batam 29442, Phone: (0778) 7437111 \\ Email: alfis.setyawan@gmail.com; \\ Nur Hadiyati \\ Fakultas Hukum Universitas Internasional Batam \\ Jl. Gajah Mada, Baloi - Sei Ladi, Batam 29442, Phone: (0778) 7437111 \\ Email: hadiyati@uib.ac.id
}

\begin{abstract}
Therapeutic agreements are agreements made between doctors and patients in general related to the health efforts that will be taken. The practice of therapeutic agreements sometimes raises awareness for patients who have minimal knowledge of medicine and tend to be harmed. This leads to therapeutic agreements needing an in-depth legal review. The issues to be examined are urgency agreements are examined from civil law and the application of the principle of proportionality in therapeutic agreements generally. The research uses normative legal research with conceptual approaches. It is found that the application of the principle of proportionality in therapeutic agreements and the fulfilling of elements in civil law can be an effort to provide justice for all parties both doctors and patients.
\end{abstract}

Keywords: The Principle Of Proportionality, Patients, Doctors, Agreements Therapeutic.

ABSTRAK
Perjanjian terapeutik merupakan kesepakatan yang dilakukan antara dokter dan pasien pada umumnya terkait dengan upaya kesehatan yang akan ditempuh. Praktek dari perjanjian terapeutik terkadang menimbulkan kewaspadaan bagi pasien yang memiliki pengetahuan yang minim terkait dunia kedokteran dan cenderung pasien menjadi pihak yang dirugikan. Hal ini menyebabkan perjanjian terapeutik perlu kajian hukum yang mendalam. Permasalahan yang akan diteliti yaitu urgensi perjanjian terpautik ditinjau dari hukum keperdataan dan penerapan asas proporsionalitas dalam perjanjian terapeutik umumnya. Penelitian menggunakan penelitian hukum normatif dengan pendekatan konseptual. Ditemukan adanya penerapan asas proporsionalitas dalam perjanjian terapeutik serta dipenuhinya unsur-unsur dalam hukum keperdataan dapat menjadi upaya dalam memberikan keadilan bagi seluruh pihak baik Dokter maupun pasien.

Kata Kunci: Asas Proposionalitas, Pasien, Dokter, Perjanjian Terapautik.

\section{PENDAHULUAN}

Praktik kedokteran merupakan inti dari berbagai kegiatan dalam penyelenggaraan upaya kesehatan yang merupakan hak tiap Warga Negara Indonesia yang dijamin oleh Konstitusi dan Perundang-undangan. Dalam penyelenggaraannya berdasarkan Pasal 39
Undang-Undang Nomor 29 Tahun 2004 tentang Praktik Kedokteran disebutkan bahwa Praktik kedokteran diselenggarakan berdasarkan pada kesepakatan antara dokter atau dokter gigi dengan pasien dalam upaya untuk pemeliharaan kesehatan, pencegahan penyakit, peningkatan kesehatan, pengobatan 
penyakit dan pemulihan kesehatan, security of person" serta dalam Pasal 1 kesepakatan ini pada umumnya disebut Covenant on Civil and Political Rights 1996, perjanjian terapautik.

Dalam praktiknya muncul polemik "all people have the rights of self determinations", sehingga dalam perjanjian tersendiri apakah kondisi pasien telah cukup terlindungi atau tidak dirugikan oleh dokter dimana pasien pada umumnya adalah masyarakat awam yang memliki pengetahuan minim akan dunia kedokteran, masyarakat tidak memiliki indikator pasti apakah dokter telah berusaha terkait kesembuhan yang disepakati. Untuk mengatasi kekhawatiran yang timbul ini perlu penerapan asas proporsionalitas dalam pelaksanaan perjanjian terapuatik.

Objek dari perjanjian terapeutik adalah upaya untuk mewujudkan kesehatan bukan hasil kesembuhan dari suatu penyakit. Topik kesehatan menjadi hal yang sensitif karena kesehatan merupakan hak asasi manusia, hal ini dijamin baik dalam lingkup nasional maupun internasional. Dalam lingkup nasional disebutkan dalam Pasal $28 \mathrm{H}$ ayat (1) UUD NRI Tahun 1945, “setiap orang berhak hidup sejahtera lahir dan batin, bertempat tinggal dan mendapatkan lingkungan hidup yang baik dan sehat serta berhak memperoleh pelayanan kesehatan". Pada lingkup terapeutik, pasien memiliki kedudukan yang sama dengan dokter atau tenaga kesehatan sehingga pasien berhak menentukan tindakan medis yang boleh dan tidak boleh dilakukan terhadap tubuhnya.

Secara sederhana alur terjadinya perjanjian terapeutik dimulai dari pasien yang berkunjung ke Rumah Sakit untuk berkonsultasi masalah kesehatan ke dokter, selanjutnya dokter melakukan observasi dan mendiagnosa, setelah itu baru merencanakan suatu terapi dengan memberikan resep atau suntikan atau operasi, ketika pasien setuju inilah dikenal dengan informed consent, disanalah terjadi perjanjian terapautik. Dilihat dari alurnya maka perjanjian terapeutik secara yuridis termasuk dalam kategori perikatan berdasarkan daya upaya/usaha maksimal (inspanningsverbintenis) bukan termasuk perikatan yang berorientasi pada hasil kerja (resultaatverbintenis), namun sebagaimana hubungan kontraktual pada umumnya dikenal didalamnnya penerapan asas proporsional sebagai satu dari sekian asas dalam internasional disebutkan dalam Pasal 3 keperdataan, jika asas tersebut dilanggar Deklarasi Hak-Hak Asasi Manusia oleh berpotensi kontrak dapat dimintakan Perserikatan Bangsa-Bangsa tahun 1948 pembatalannya melalui Ketua Pengadilan yaitu, "every one has the right to life and Negeri."

1 ___ (22 Juli 2017), Kontrak Abaikan Asas Proporsionalitas Dapat Dibatalkan, Diakses pada tanggal 24 Februari 2020, Dari Litigasi: https://litigasi.co.id/kontrak-abaikan-asas-proporsionalitas-dapat-dibatalkan. 
Meski demikian, Perjanjian terapeutik antara dokter dan pasien ini tidak jarang kurang diperhatikan, baik oleh seorang dokter ataupun seorang pasien. ${ }^{2}$ Sehingga kemudian dipandang perlu untuk memahami secara mendalam urgensi dari perjanjian terapeutik ditinjau dari pembidangan hukum perdata dan secara spesifik dalam penerapan asas proporsionalitas pada perjanjian teurapetik tersebut.

\section{PEMBAHASAN}

Urgensi Perjanjian Terapeutik Ditinjau Dari Hukum Keperdataan

Dalam dinamika hukum di Indonesia seiring dengan sejarah bangsa, sistem hukum menjadi suatu warisan dari masa penjajahah, salah satunya adalah bidang hukum perdata. Warisan di bidang hukum perdata masih kental rasa Belanda-nya hingga sekarang dengan masih berlakunya Burgerlijke Wetboek (BW) dan Het Herziene Indonesische Reglement (HIR)/ Rechtsreglement voor de Buitengewesten $(\mathrm{RBg}){ }^{3}$ Hukum perdata sendiri adalah ketentuan yang mengatur hak dan kepentingan antar individu dalam masyarakat.

Dalam praktik kedokteran sebagai inti dari berbagai kegiatan dalam penyelenggaraan upaya kesehatan juga tidak terlepas dari aspek hukum keperdataan, salah satu bentuknya adalah perjanjian terapeutik. Perjanjian terapeutik pada dasarnya mempertegas hubungan hukum antara pemberi dan penerima layanan kesehatan, yang dalam tulisan ini dibatasi dalam hubungan antara dokter dan pasien ${ }^{4}$.

Pada awal mulanya hubungan dokter dengan pasien bersifat paternalistik. ${ }^{5}$ Terdapat ketidakseimbangan hubungan antar dokter dengan pasien, dimana pada umumnya Pasien memiliki posisi lebih rendah dibandingkan dokter. Pengistilaan paternalisitik ini terilustrasikan dengan baik, dimana pasien tunduk terkait kesembuhannya layaknya seorang anak pada dokter yang bertindak as father know the best yang memberikan semua masukan dengan asumsi mengetahui yang terbaik untuk anak atau pasien.

Hubungan demikian bukanlah merupakan bentuk ideal. Menurut Smith dan Newton model hubungan yang paling cocok adalah virtue based dimana adanya dialog untuk menjaga jalannya komunikasi antar dokter dan pasien guna tercapainya tujuan utama dari praktik kedokteran yakni upaya kesembuhan pasien, guna terlenggaranya hak dan

\footnotetext{
2 Bayu Winarko dan Mudiana Permata Sari, ), Tinjauan Yuridis Sahnya Perjanjian Terapeutik dan Perlindungan Hukum Bagi Pasien, Private Law, Volume , Nomor _. Hlm. 4.

3 __ (12 September 2011), Gerbang untuk Memahami Hukum Perdata Indonesia, Diakses pada tanggal 1 April 2020, Dari Hukum Online: https://www.hukumonline.com/berita/baca/lt4e6da6a1b9b56/gerbang-untukmemahami-hukum-perdata-indonesia/

4 Yovita Arie Mangesti dan Azmi Syahputra, (__ _ 2019), Elaborasi Nilai Pancasila pada Perjanjian Terapeutik dalam Rangka Pembaharuan Hukum Kesehatan, Jurnal Jurisprudence, Volume 9, Nomor 1. Hlm. $1-16$.
} 
kewajiban antara dokter dan pasien sesuai dengan porsi dan peranan masing-masing. ${ }^{6}$

Hak dan kewajiban ini dijabarkan dalam Surat Edaran Dirjen Pelayanan Medik No. YM 02.04.3.5.2504 tentang Pedoman Hak dan Kewajiban Pasien, Dokter, dan Rumah Sakit sebagai berikut:

Tabel 1. Jumlah Hak dan Kewajiban Pasien, Dokter, dan Rumah Sakit

\begin{tabular}{|c|c|c|c|}
\hline & Pasien & Dokter & $\begin{array}{c}\text { Rumah } \\
\text { Sakit }\end{array}$ \\
\hline Hak & 16 & 9 & 6 \\
\hline Kewajiban & 5 & 12 & 13 \\
\hline
\end{tabular}

Secara terperinci berkenaan hak yang melekat pada pasien terdiri dari: 1) Pasien berhak memperoleh informasi mengenai tata tertib dan peraturan yang berlaku di rumah sakit; 2) Pasien berhak atas pelayanan yang manusiawi, adil dan jujur; 3) Pasien berhak memperoleh pelayanan medis yang bermutu sesuai dengan standar profesi kedokteran/kedokteran gigi dan tanpa diskriminasi;

4) Pasien berhak memperoleh asuhan keperawatan sesuai dengan standar profesi keperawatan; 5) Pasien berhak memilih dokter dan kelas perawatan sesuai dengan keinginannya dan sesuai dengan peraturan yang berlaku di rumah sakit; 6) Pasien berhak dirawat oleh dokter yang secara bebas menentukan pendapat klinis dan pendapat etisnya tanpa campur tangan dari pihak luar; 7) Pasien berhak meminta konsultasi kepada dokter lain yang terdaftar di rumah sakit tersebut (second opinion) terhadap penyakit yang dideritanya, sepengetahuan dokter yang merawat; 8) Pasien berhak atas "privacy" dan kerahasiaan penyakit yang diderita termasuk data-data medisnya; 9) Pasien berhak mendapat informasi yang meliputi: a) Penyakit yang diderita; b) Tindakan medik apa yang hendak dilakukan; c) Kemungkinan penyulit sebagai akibat tindakan tersebut dan tindakan untuk mengatasinya; d) Alternatif terapi lainnya; e) prognosanya; dan f) Perkiraan biaya pengobatan; 10) Pasien berhak menyetujui/ memberikan izin atas tindakan yang akan dilakukan oleh dokter sehubungan dengan penyakit yang dideritanya; 11) Pasien berhak menolak tindakan yang hendak dilakukan terhadap dirinya dan mengakhiri pengobatan serta perawatan atas tanggung jawab sendiri sesudah memperoleh informasi yang jelas tentang penyakitnya; 12) Pasien berhak didampingi keluarganya dalam keadaan kritis; 13) Pasien berhak menjalankan ibadah sesuai agama/kepercayaan yang dianutnya selama hal itu tidak mengganggu pasien lainnya; 14) Pasien berhak atas keamanan dan keselamatan dirinya selama dalam perawatan di rumah sakit; 15) Pasien berhak mengajukan usul, saran, perbaikan atas perlakuan rumah sakit terhadap dirinya; 16) Pasien berhak menerima atau menolak bimbingan moril maupun spiritual.

6 Budi Sampurna, (__ _ _ 2001), Wewenang dan Tanggungjawab Daripada Tindakan Bedah Kulis Kosmetik, Majalah Kedokteran Indonesia, Volume 11, Nomor 11. Hlm. 417. 
Sedangkan kewajiban yang dimiliki pasien terdiri atas 5 poin yakni: 1) Pasien dan keluarganya berkewajiban untuk mentaati segala peraturan dan tata-tertib rumah sakit; 2) Pasien berkewajiban untuk mematuhi segala instruksi dokter dan perawat dalam pengobatannya; 3) Pasien berkewajiban memberikan informasi dengan jujur dan selengkapnya tentang penyakit yang diderita kepada dokter yang merawat; 4) Pasien dan atau penanggungnya berkewajiban untuk melunasi semua imbalan atas jasa pelayanan rumah sakit/dokter. 5) Pasien dan atau penanggungnya berkewajiban memenuhi halhal yang telah disepakati/perjanjian yang telah dibuatnya.

Untuk dokter, hak yang melekat pada adalah sebagai berikut: 1) Dokter berhak mendapat perlindungan hukum dalam melaksanakan tugas sesuai dengan profesinya; 2) Dokter berhak untuk bekerja menurut standar profesi serta berdasarkan hak otonomi, (seorang dokter, walaupun ia berstatus hukum sebagai karyawan rumah sakit, namun pemilik atau direksi rumah sakit tidak dapat memerintahkan untuk melakukan sesuatu tindakan yang menyimpang dari standar profesi atau keyakinannya); 3) Dokter berhak untuk menolak keinginan pasien yang bertentangan dengan peraturan perundang-undangan, profesi dan etika; 4) Dokter berhak menghentikan jasa profesionalnya kepada pasien apabila misalnya hubungan dengan pasien sudah berkembang begitu buruk sehingga kerjasama yang baik tidak mungkin diteruskan lagi, kecuali untuk pasien gawat darurat dan wajib menyerahkan pasien kepada dokter lain; 5) Dokter berhak atas privacy dan berhak menuntut apabila nama baiknya dicemarkan oleh pasien dengan ucapan atau tindakan yang melecehkan atau memalukan; 6) Dokter berhak mendapat informasi lengkap dari pasien yang dirawatnya atau dari keluarganya; 7) Dokter berhak atas informasi atau pemberitahuan pertama dalam menghadapi pasien yang tidak puas terhadap pelayanannya; 8) Dokter berhak untuk diperlakukan adil dan jujur, baik oleh rumah sakit maupun oleh pasien; dan 9) Dokter berhak untuk mendapat imbalan atas jasa profesi yang diberikannya berdasarkan perjanjian dan atau ketentuan/peraturan yang berlaku di rumah sakit tersebut.

Kewajiban yang melekat pada dokter adalah sebagai berikut: 1) Dokter wajib mematuhi peraturan rumah sakit sesuai dengan hubungan hukum antara dokter tersebut dengan rumah sakit; 2) Dokter wajib memberikan pelayanan medis sesuai dengan standar profesi dan menghormati hak-hak pasien; 3) Dokter wajib merujuk pasien ke dokter lain/rumah sakit lain yang mempunyai keahlian/kemampuan yang lebih baik, apabila ia tidak mampu melakukan suatu pemeriksaan atau pengobatan. 4) Dokter wajib memberi kesempatan kepada pasien agar senantiasa dapat 
berhubungan dengan keluarga dan dapat menjalankan ibadah sesuai keyakinannya; 5) Dokter wajib merahasiakan segala sesuatu yang diketahuinya tentang seorang penderita, bahkan juga setelah penderita itu meninggal dunia; 6) Dokter wajib melakukan pertolongan darurat sebagai suatu tugas perikemanusiaan, kecuali bila ia yakin ada orang lain bersedia dan mampu memberikannya; 7) Dokter wajib memberikan informasi yang adekwat tentang perlunya tindakan medik yang bersangkutan serta risiko yang dapat ditimbulkannya; 8) Dokter wajib membuat rekam medis yang baik secara berkesinambungan berkaitan dengan keadaan pasien; 9) Dokter wajib terus menerus menambah ilmu pengetahuan dan mengikuti perkembangan ilmu kedokteran/kedokteran gigi; 10) Dokter wajib memenuhi hal-hal yang telah disepakati/perjanjian yang telah dibuatnya; 11) Dokter wajib bekerjasama dengan profesi dan pihak lain yang terkait secara timbal balik dalam memberikan pelayanan kepada pasien; dan 12) Dokter wajib mengadakan perjanjian tertulis dengan pihak rumah sakit.

Pihak rumah sakit sebagai instansi sekaligus wadah pertemuan dokter dan pasian juga memiliki hak dan kewajiban yang melekat padanya. Rumah sakit memiliki hak sebagai berikut: 1) Rumah rakit berhak membuat peraturan-peraturan yang berlaku di rumah sakitnya sesuai dengan kondisi/keadaan yang ada di rumah sakit tersebut (hospital by laws); 2) Rumah Sakit berhak mensyaratkan bahwa pasien harus mentaati segala peraturan rumah sakit; 3) Rumah sakit berhak mensyaratkan bahwa pasien harus mentaati segala instruksi yang diberikan dokter kepadanya; 4) Rumah sakit berhak memilih tenaga dokter yang akan bekerja di rumah sakit melalui panitia kredensial; 5) Rumah sakit berhak menuntut pihak-pihak yang telah melakukan wanprestasi (termasuk pasien, pihak ketiga, dan lain-lain); dan 6) Rumah sakit berhak mendapat perlindungan hukum.

Kewajiban yang harus dilaksanakan oleh pihak rumah sakit sebagai berikut: 1) Rumah sakit wajib mematuhi perundangan dan peraturan yang dikeluarkan oleh Pemerintah; 2) Rumah sakit wajib memberikan pelayanan kepada pasien tanpa membedakan suku, ras, agama, seks dan status sosial pasien; 3) Rumah sakit wajib merawat pasien sebaikbaiknya dengan tidak membedakan kelas perawatan (duty of care); 4) Rumah sakit wajib menjaga mutu perawatan dengan tidak membedakan kelas perawatan (quality of care); 5) Rumah sakit wajib memberikan pertolongan pengobatan di unit gawat darurat tanpa meminta jaminan materi terlebih dahulu; 6) Rumah sakit wajib menyediakan sarana dan peralatan umum yang dibutuhkan. 7) Rumah sakit wajib menyediakan sarana dan peralatan medik (medical equipment) sesuai dengan standar yang berlaku; 8) Rumah sakit wajib menjaga agar semua sarana dan peralatan senantiasa dalam keadaan siap pakai (ready for use); 9) Rumah sakit wajib merujuk 
pasien kepada rumah sakit lain apabila tidak memiliki sarana, prasarana, peralatan dan tenaga yang diperlukan. 10) Rumah sakit wajib mengusahakan adanya sistem, sarana dan prasarana pencegahan kecelakaan dan penanggulangan bencana, 11) Rumah sakit wajib melindungi dokter dan memberikan bantuan administrasi dan hukum bilamana dalam melaksanakan tugas dokter tersebut mendapat perlakuan tidak wajar atau tuntutan hukum dari pasien atau keluarganya; 12) Rumah sakit wajib mengadakan perjanjian tertulis dengan para dokter yang bekerja di rumah sakit tersebut; dan 13) Rumah sakit wajib membuat standar dan prosedur tetap baik untuk pelayanan medik, penunjang medik, non medik.

Jika dipahami secara sederhana secara obligatoir maka hak yang dimiliki oleh pasien menjadi kewajiban dokter dan/atau rumah sakit, demikian juga sebaliknya. Namun setelah diuraikan sebagiamana diatas terdapat perbedaan dimana tidak semua hak pasien menjadi kewajiban dokter dan/atau rumah sakit.

Hal ini dikarenakan kedudukan Pasien tidak seimbang dengan dokter, sehingga untuk menyeimbangkannya Pasien memiliki lebih banyak hal yang banyak sedangkan dokter dan rumah sakit justru kewajiban yang diberi banyak. Upaya pelaksanaan penyetaraan melalui model virtue based dalam praktik kedokteran ini yang kemudian dikonkritkan dan dikenal dengan istilah perjanjian/transaksi terapeutik dimana pasien dan dokter dipersetarakan kedudukannya.

Penggunaan istilah perjanjian dalam perjanjian/transaksi terapeutik yang menjadikannya sebagai bagian dari praktik kedokteran yang lekat dengan hukum keperdataan sebagai muara hukum yang mengatur hubungan perseorangan. Dengan disesuaikan pelaksanaan perjanjian terapeutik dengan hukum dalam hal ini hukum perdata maka niscaya dapat dicapainya keadilan sebagaimana adegium yang berkembang Equum Et Bonum Est Lex Legum (apa yang adil dan baik adalah hukumnya hukum).

Pengertian atau penggunaan istilah perjanjian terapeutik tidak disebutkan secara eksplisit dalam Kitab Undang-Undang Hukum Perdata (KUHPdt), namun berdasarkan ketentuan dalam Pasal 1319 KUHPdt, "Semua perjanjian, baik yang mempunyai suatu nama khusus, maupun yang tidak terkenal dengan suatu nama tertentu, tunduk pada peraturan umum yang termuat dalam bab ini dan bab-bab terdahulu" maka perjanjian terapeutik masuk sebagai bentuk perjanjian yang mengikuti ketentuan yang ada dalam KUHPdt.

Perjanjian diatur dalam Buku III (Ketiga) KUHPdt yakni tentang Hukum Perikatan. Perjanjian menurut Pasal 1313 KUHPerdata adalah "suatu perbuatan dengan mana satu orang atau lebih mengikatkan dirinya terhadap satu orang lain atau lebih”. Salah satu dari sekian hal yang melekat dalam 
pengaturan berkenaan dengan perjanjian adalah unsur yang menjadi syarat sahnya perjanjian sebagaimana disebutkan dalam Pasal 1320 KUHPdt sebagai berikut:

1. kesepakatan mereka yang mengikatkan dirinya (toestetning van degenen die zich verbinden);

2. kecakapan untuk membuat suatu perikatan (de bekwaamheid om eene verbintenis aan te gaan);

3. suatu pokok persoalan tertentu (een bepaald onderwerp);

4. suatu sebab yang tidak terlarang (eene geoorloofdeoorzaak).

Unsur syarat pertama dan kedua disebut syarat subjektif karena berkenaan dengan para subjek atau pihak yang membuat perjanjian itu. Sedangkan unsur syarat ketiga dan keempat disebut syarat objektif karena berkenaan dengan objek dalam perjanjian tersebut. Tidak dipenuhinya syarat-syarat tersebut mengakibatkan suatu perjanjian dapat dibatalkan atau batal demi hukum.

Tidak dipenuhinya syarat subjektif menjadikan suatu perjanjian dapat dibatalkan dalam artian perjanjian menjadi tidak sempurna dan dapat dimohonkan pembatalannya, perjanjiannya sendiri tetap mengikat kedua belah pihak, selama tidak dibatalkan (oleh hakim) atas permintaan pihak yang berhak meminta pembatalan tadi (pihak yang tidak cakap atau pihak yang memberikan sepakatnya secara tidak bebas).

Sedangkan tidak dipenuhinya syarat objektif mengakibatkan suatu perjanjian batal demi hukum dalam artian perjanjian dianggap tidak pernah ada atau kembali dalam kondisi semula dimana tidak ada dilahirkan suatu perjanjian dan tidak pernah ada suatu perikatan. Unsur-unsur yang dipersyaratkan menjadi koridor untuk memastikan agar perjanjian berjalan sebagaimana mestinya.

Perjanjian terapeutik lahir dari ketentuan pada Pasal 39 Undang-Undang Nomor 29 tahun 2004 tentang Praktik Kedokteran disebutkan bahwa Praktik kedokteran diselenggarakan berdasarkan pada kesepakatan antara dokter atau dokter gigi dengan pasien dalam upaya untuk pemeliharaan kesehatan, pencegahan penyakit, peningkatan kesehatan, pengobatan penyakit dan pemulihan kesehatan. Selanjutnya bentuk kesepakatan ini dapat ditemukan melalui informed consent.

Keputusan Dirjen Pelayanan Medik Nomor HK.00.06.3.5.1866 tentang Pedoman Persetujuan Tindakan Medis menjabarkan pengertian informed consent secara perkata. informed berarti telah mendapat informasi dan consent berarti persetujuan (ijin). Jadi informed consent adalah pemyataan setuju atau ijin dari pasien yang diberikan secara bebas, rasional, tanpa paksaan (voluntary) tentang tindakan kedokteran yang akan diiakukan terhadapnya sesudah mendapat informasi cukup tentang tindakan dokter dimaksud.

Informed consent diberikan oleh seorang pasien yang sehat mental dan yang memang berhak memberikannya dari segi hukum yakni dalam Pasal 1329 KUH Perdata menyebutkan 
setiap orang adalah cakap untuk membuat suatu perjanjian, kecuali jika oleh undangundang dinyatakan tidak cakap membuat perjanjian.

Mereka yang oleh undang-undang dinyatakan tidak cakap membuat perjanjian, sebagaimana diatur dalam Pasal 1330 KUH Perdata, yaitu: 1) Anak yang belum dewasa; 2) Orang yang berada di bawah pengampuan;

3) Perempuan yang telah kawin. Namun, berdasarkan SEMA No. 3/1963 jo. Pasal 31 UU No. 1/1974, maka meski terikat dalam perkawinan telah ada kesetaraan dan menjadikan mereka cakap untuk melakukan perbuatan hukum sendiri dikarenakan; dan 4) Orang yang dilarang oleh undang-undang untuk melakukan perbuatan tertentu.

Maka dalam hal ini dalam Perjanjian Terapeutik yang ideal unsur pertama dan kedua yakni kecakapan para pihak haruslah dipenuhi untuk melakukan kesepakatan menyetujui tindakan medis yang akan/harus ditempuh. Secara sederhana bagi pasien yang dalam keadaan tidak memenuhi syarat untuk melakukan perjanjian dapat diwakilkan oleh wali atau pihak yang telah diberi surat kuasa dan tidak dilarang oleh undang-undang, terkait kuasa ini sebagaimana disebutkan dalam KUHPdt Pasal 1792 KUHPerdata yang berbunyi: "Pemberian kuasa adalah suatu perjanjian dengan mana seorang memberikan kekuasaan kepada seorang lain, yang menerimanya, untuk atas namanya menyelenggarakan suatu urusan”, sedangkan dokter dan tenaga kesehatan harus mempunyai kecakapan yang diperlukan oleh pasien, yang dapat dibuktikan dengan sertifikat atau surat dokumen relevan.

Pelaksanaan informed consent dianggap benar jika persetujuan atau penolakan tindakan medis diberikan untuk tindakan medis yang dijelaskan secara detail dan terperinci (the consent must be for what will be actually performed), diberikan tanpa paksaan (voluntary), diberikan setelah mendapatkan informasi dan penjelasan yang diperlukan sesuai ketentuan yang ada.

Perjanjian terapeutik menjanjikan upaya dokter untuk mencapai kesembuhan atau meningkatkan kualitas hidup Pasien untuk dilakukan bukan kesembuhan pasien, karena jika kesembuhan pasien dijadikan objek, akan menyudutkan dokter dikarenakan topik berkenaan dengan kesehatan adalah hal yang sensitif, sehingga dalam hal terjabarkan syarat objektif yang dipenuhi dalam perjanjian terapeutik dimana terdapat kejelasan akan hal yang diperjanjikan dan hal tersebut didasari oleh ketentuan yang ada sehingga tidak termasuk dilarang berkenaan dengan kesusilaan, ketertiban umum, atau peraturan perundang-undangan.

Perjanjian/transaksi terapeutik yang dapat dilihat melalui informed consent merupakan perlindungan hukum bagi Pasien dan dokter, dalam artian bagi dokter menjadi pembenar/ legalitas/keabsahan dari tindakan medis yang ditempuh sesuai persertujuan, sedangkan bagi 
Pasien informed consent berguna untuk memberikan gambaran apakah tindakan medis yang diterima sesuai dengan kebutuhan.

Hukum yang umum di berbagai Negara menyatakan bahwa akibat dari ketiadaan informed consent setara dengan kelalaian/ keteledoran. $^{7}$ Namun, dalam beberapa hal, ketiadaan informed consent tersebut dapat disetarakan dengan perbuatan kesengajaan bila: 1) Pasien sebelumnya menyatakan tidak setuju terhadap tindakan dokter, tetapi dokter tetap melakukan tindakan tersebut; 2) Jika dokter dengan sengaja melakukan tindakan misleading tentang risiko dan akibat dari tindakan medis yang diambilnya; 3) Jika dokter dengan sengaja menyembunyikan resiko dan akibat dari tindakan medis yang diambilnya; 4) Informed consent diberikan terhadap prosedur medis yang berbeda secara substansial dengan yang dilakukan oleh dokter. Dokter dapat dituntut pidana dan digugat perdata, jika dalam tindakan medis terjadi malpraktik, dan informed consent dalam hal ini berfungsi sebagai pembuktian apakah benar telah terjadinya malpraktek.

Setelah melihat perjanjian terapeutik dari unsur-unsur persyaratan yang harus dipenuhi secara lumrah perjanjian dapat dilakukan. Ada dua cara melakukan perjanjian terapeutik ini yaitu secara lisan dan tulisan. Secara lisan umumnya dilakukan untuk tindakan yang sifatnya ringan dan biasa, sedangkan tulisan pada umumnya dilakukan pada tindakan pengobatan atau perawatan yang mempunyai dan memiliki risiko yang sangat tinggi contohnya operasi, harus disetujui secara tertulis.

Perjanjian terapeutik yang dibuat oleh dokter dan pasien berlaku sebagaimana undang-undang mewajibkan para pihak memenuhi hak dan kewajibannya masingmasing sesuai dengan hal yang diperjanjikan.

Untuk mengalihkan pasien, dokter yang bersangkutan harus minta persetujuan pasien atau keluarganya, ${ }^{8}$ sedangkan untuk berakhirnya perjanjian terapeutik, terdapat beberapa cara berakhirnya hubungan dokter dan pasien tersebut, yakni sebagai berikut: 1) Sembuhnya pasien dari keadaan sakitnya dan sang dokter menganggap tidak diperlukan lagi pengobatan, sehingga tidak ada manfaatnya lagi pasien untuk meneruskan pengobatannya; 2) Dokternya mengundurkan diri; 3) Pengakhiran oleh pasien; 4) Meninggalnya pasien; 5) Meninggalnya atau tidak mampu menjalani lagi (incapacity) profesinya dokter; 6) Sudah selesainya kewajiban dokter seperti ditentukan di dalam kontrak; 7) Dalam kasus gawat darurat, apabila dokter yang mengobati

7 Achmad Busro, (9 November 2018), Aspek Hukum Persetujuan Tindakan Medis (Inform Consent) dalam Pelayanan Kesehatan, Law, Development \& Justice Review, Volume 1, Nomor 1. Hlm. 14.

8 Evy Savitri Gani, (__, Desember 2018), Tinjauan Yuridis Kedudukan Hukum Para Pihak Dalam Perjanjian Terapeutik, Tahkim: Jurnal Hukum dan Syariah, Volume XIV, Nomor 2. Hlm. 169. 
atau dokter pilihan pasien sudah datang, atau terdapat penghentian keadaan kegawatdaruratannya; 8) Lewat jangka waktu, apabila kontrak medik itu ditentukan untuk jangka waktu tertentu; 9) Persetujuan kedua belah pihak antara dokter dan pasiennya bahwa hubungan. dokter dan pasien itu sudah diakhiri. ${ }^{9}$

\section{Penerapan Asas Proporsionalitas dalam Perjanjian Terapeutik}

Hubungan antara dokter dan pasien telah diutarakan sebelumnya berada dalam ketidakseimbangan dimana pasien cenderung memilik kedudukan yang lebih rendah sehingga kemudian lahirlah perjanjian terapeutik sebagai upaya menjembatani dokter dan pasien yang dalam tataran ideal mengikuti ketentuan yang ada dihukum perdata.

Guna mengoptimalkan tujuan dari penyelenggaraan Perjanjian Terapeutik perlu diperhatikan penerapan asas proporsionalitas. Asas proporsionalitas ini hadir dalam rangka menjawab secara teoritis mengenai bagaimana mengakomodir kepentingan para pihak yang melakukan hubungan kontraktual.

Dengan adanya asas proporsionalitas dalam perjanjian ini diharapkan kontrak yang tercipta adalah kontrak yang dapat mengakomodir kepentingan di antara para pihak, baik hak dan kewajiban secara tepat. ${ }^{10}$

Asas proporsional berasal dari kata "proporsi" dalam bahasa inggris - proportion dan dalam bahasa belanda - proportie yang berarti perbandingan, perimbangan. Sedangkan proporsional sendiri dalam bahasa inggris - proportional dan bahasa belanda proportioneel yang berarti sesuai proporsi, sebanding, seimbang, dan berimbang.

Maka dapat diartikan asas proporsionalitas dalam perjanjian adalah adanya keseimbangan dimana pertukaran hak dan kewajiban para pihak sesuai proporsi atau bagiannya. Asas proposionalitas tidak menuntut hasil yang selalu seimbang-sama (equilibrium-matematis) sebagaimana asas keseimbangan, oleh karenanya perbedaan hasil dianggap adil dan diterima secara wajar apabila proses pertukaran hak dan kewajiban berlangsung proporsional.

Penerapan asas proposionalitas dengan menimbang ketidaksetaraan posisi dokter dan pasien menjadi jalan untuk tercapainya keadilan antara dokter dan pasien seiring perkembangan zaman untuk lebih mudah dicapai. Keterbukaan peluang untuk bernegosiasi bagi para pihak pada saat ini seiring dengan kemajuan teknologi dapat dilihat dari sistem informasi Rumah Sakit

\footnotetext{
$9 \quad$ Ibid, hlm 171

10 Xavier Nugraha, (16 Mei 2019), Asas Proporsionalitas Sebagai Solusi Terciptanya Kontrak yang Saling Menguntungkan Para Pihak, Diakses pada tanggal 2 April 2020, Dari Unair News: http://news.unair.ac.id/2019/05/16/asas-proporsionalitas-sebagai-solusi-terciptanya-kontrak-yang-salingmenguntungkan-para-pihak/.
} 
yang memberikan jadwal praktik dokter dalam melakukan perawatan, bahkan beberapa rumah sakit juga sudah menampilkan profil atau riwayat hidup singkat dokter seperti salah satu fitur yang ditawarkan https://www.alodokter.com/ yang memberikan kebebasan bagi pasien untuk memilih calon dokter yang akan memberikan pelayanan kesehatan.

Selain bantuan dari kemajuan sistem informasi dan teknologi, sejatinya hal yang diperlukan adalah keterbukaan informasi bagi publik. Hak warga negara untuk memperoleh informasi publik merupakan hak konstitusional sebagaimana dijamin dalam Pasal 28F UUD NRI Tahun 1945, “Setiap orang berhak untuk berkomunikasi dan memperoleh informasi untuk mengembangkan pribadi dan lingkungan sosialnya, serta berhak untuk mencari, memperoleh, memiliki, menyimpan, mengolah, dan menyampaikan informasi dengan menggunakan segala jenis saluran yang tersedia”. Sehingga idealnya sebelum menjalani terapi, pasien terlebih dahulu diberi penjelasan memahami track record dari dokter yang akan merawatnya, setidaknya kompetensi yang dimiliki oleh dokter berkesesuaian dengan keluhan yang dialami untuk ditangani.

Dalam penanganan sesuai dengan kompetensi yang dimiliki, dokter melakukan anamnesa (tanya jawab tentang penyakit) yang diikuti dengan pemeriksaan fisik, kadang-kala dilengkapi dengan diagnostik guna membantu menegakkan diagnosanya berupa pemeriksaan radiologi atau pemeriksaaan laboratorium, setelah diagnosa ditegakkan dilanjutkan dengan merencanakan suatu terapi dengan memberikan resep/ suntikan/operasi/tindakan medisnya lainnya.

Dokter dalam hal ini menjalankan kewajibannya dalam memberikan usaha terbaik untuk mencapai kesembuhan, sedangkan pasien menerima haknya yakni menerima terapi sebagai upaya kesembuhan, inilah yang terjadi melalui perjanjian terapeutik yakni pertukaran hak dan kewajiban berdasarkan kepercayaan.

Dalam pemberian penjelasan dan pelaksanaan upaya kesehatan dokter harus berada dalam posisi setara dengan pasien. Upaya menjaga kesetaraan sebagai perwujudan diterapkannya asas proporsionalitas ini sebagaimana diamanatkan dalam Kode Etik dokter khususnya dalam Pasal 8, "Seorang dokter wajib, dalam setiap praktik medisnya, memberikan pelayanan secara kompeten dengan kebebasan teknis dan moral sepenuhnya, disertai rasa kasih sayang (compassion) dan penghormatan atas martabat manusia".

Dalam Pasal 9, "Seorang dokter wajib bersikap jujur dalam berhubungan dengan pasien dan sejawatnya, dan berupaya untuk mengingatkan sejawatnya pada saat menangani pasien dia ketahui memiliki kekurangan dalam karakter atau kompetensi, 
atau yang melakukan penipuan atau penggelapan", dan dalam Pasal 10, "Seorang dokter wajib menghormati hak-hak pasien, teman sejawatnya, dan tenaga kesehatan lainnya, serta wajib menjaga kepercayaan pasien"

Sehingga dalam praktiknya pasien berhak secara bebas dan mandiri untuk dapat melanjutkan atau tidak melanjutkan terapi sebagai upaya kesehatan, dan jikalau memenuhi kendala dokter sebagai tenaga kesehatan diharapkan dapat memberikan solusi sehingga kewajiban dan hak dari masing-masing pihak dapat terpenuhi. Karena hakikat dari prinsip informed consent sebagai perwujudan dari perjanjian teraputik adalah persetujuan dilakukan setelah memperoleh informasi secara lengkap dari dokter dan biasanya pihak dokter maupun rumah sakit akan meminta persetujuan pasien ataupun keluarga pasien (bagi pasien di bawah umur atau tidak sadar) secara tertulis dengan menandatangani formulir persetujuan tindakan medis. Disinilah lagi-lagi merupakan bentuk komunikasi dalam hubungan dokter dan pasien dilaksanakan secara proporsional.

Sejatinya ukuran proporsionalitas pertukaran hak dan kewajiban didasarkan pada nilai-nilai kesetaraan (equitability), kebebasan, distribusi-proporsional, tentunya juga tidak dapat dilepaskan dari asas atau prinsip kecermatan (zorgvuldigheid), kelayakan (redelijkheid; reasonableness) dan kepatutan (billijkheid; equity).

Ukuran ini bukan dalam sifat matematis, asas proporsionalitas lebih menekankan proporsi pembagian hak dan kewajiban di antara para pihak yang berlangsung secara layak dan patut (fair and reasonable). ${ }^{11} \mathrm{Hal}$ ini dapat dilihat dalam pembahasan sebelumnya dimana hak dan kewajiban antara pasien, dokter, dan rumah sakit bukan dalam jumlah yang sama namun disesuaikan dengan kondisi dari masing-masing para pihak.

Umumnya untuk dapat melihat penerapan asas proporsionalitas dalam suatu perjanjian dapat melihat dari pelaksanaan kontrak bisnis komersial dimana asas proporsionalitas memiliki fungsi sebagai berikut ${ }^{12}$ :

1. Dalam tahap pra kontrak, asas proporsionalitas membuka peluang negosiasi bagi para pihak untuk melakukan pertukaran hak dan kewajiban secara fair. Oleh karena itu adalah tidak proporsional dan harus ditolak proses negosiasi dengan itikad buruk;

2. Dalam pembentukan kontrak, asas proporsional menjamin kesetaraan hak serta kebebasan dalam menentukan/mengatur proporsi hak dan kewajiban para pihak berlangsung secara fair/adil, hal ini berbeda dengan Secara umum asas keseimbangan yang sejak semula menginginkan terpenuhinya kondisi keseimbangan posisi para pihak yang berkontrak bila-

\footnotetext{
11 Agus Yudha Hernoko, “Asas Proporsionalitas sebagai Landasan Pertukaran Hak dan Kewajiban Para Pihak Dalam Kontrak Komersial”, Disertasi Universitas Airlangga, 2007. Hlm. 460.

12 Ibid. Hlm. 450.
} 
mana tidak terpenuhi maka menimbulkan gangguan terhadap isi kontrak;

3. Dalam pelaksanaan kontrak, asas proporsional menjamin terwujudnya distribusi pertukaran hak dan kewajiban menurut proporsi yang disepakati/dibebankan pada para pihak;

4. Dalam hal terjadi kegagalan dalam pelaksanaan kontrak, maka harus dinilai secara proporsional apakah kegagalan tersebut bersifat fundamental (fundamental breach) sehingga mengganggu pelaksanaan sebagaian besar kontrak atau sekedar hal-hal yang sederhana/kesalahan kecil (minor importanance). Oleh karena itu pengujian melalui asas proporsionalitas sangat menentukan dalil kegagalan pelaksanaan kontrak, agar jangan sampai terjadi penyalahgunaan oleh salah satu pihak dalam memanfaatkan klausul kegagalan pelaksanaan kontrak, semata-mata demi keuntungan salah satu pihak dengan merugikan pihak lain;

5. Bahkan dalam hal terjadi sengketa kontrak, asas proporsionalitas menekankan bahwa proporsi beban pembuktian kepada para pihak harus dibagi menurut pertimbangan yang fair/adil.

Perwujudan dari poin ke-4 dan ke-5 dalam sengketa antara dokter dan pasien yang dikenal dengan istilah sengketa medik dapat dilihat dari tersedianya berbagai alur penyelesaian. Sengketa medik merupakan perselisihan yang timbul akibat hubungan hukum antara dokter dengan pasien dalam upaya melakukan penyembuhan. ${ }^{13}$
Berdasarkan perangkat peraturan dan prosedur penyelesaian sengketa yang ada saat ini, sengketa medik dapat diselesaikan melalui jalur hukum maupun jalur etika. Dari jalur hukum, bisa melalui hukum perdata, hukum pidana, ataupun hukum perlindungan konsumen. ${ }^{14}$ Dalam aspek hukum perdata, pertanggungjawaban oleh dokter yang timbul dari perjanjian terapeutik setidaknya terdiri dari tiga pertanggungjawaban atas kerugian yang diakibatkan oleh 1) Perbuatan Melawan Hukum (Pasal 1365 KUH Perdata); 2) Lalai atau kekuranghatihatian (Pasal 1366 KUH Perdata); 3) Tanggung jawab atasan terhadap bawahan (Pasal 1367 KUH Perdata); dan diatur juga dalam dengan Undang-Undang Nomor 36 Tahun 2009 Tentang Kesehatan, pasal 56 ayat (1), Pasal 56 ayat (2), dan Pasal 56 ayat (3), dan Pasal 57 ayat (1), Pasal 57 (2), serta Pasal 58 ayat (1), Pasal 58 (2), dan Pasal 58 ayat (3) yang intinya mengatur dalam pertanggungjawaban tersebut Dokter juga wajib mengikuti Kode Etik Kedokteran Indonesia, Standar Profesi, dan Standar Prosedur Operasional serta ketentuan-ketentuan hukum administrasi dalam menjalankan pekerjaannya sebagai dokter.

Sedangkan jalur Hukum Pidana dapat dilihat melalui berbagai unsur delik baik yang diatur dalam KUHP maupun Undang-Undang Nomor 36 Tahun 2009 tentang Kesehatan,

\footnotetext{
13 Safitri Hariyani Saptogino, (14 Maret 2019), Penyeleasian Sengketa Medik di Indonesia, Diakses pada tanggal 7 April 2020, Dari Sip Law Firm: https://siplawfirm.id/penyelesaian-sengketa-medik-di-indonesia/?lang=id. 
edangkan melalui Hukum Perlindungan Konsumen kedudukan dokter \& pasien bisa dipersamakan sebagai hubungan pelaku usaha \& konsumen sehingga penyelesaian sengketa melalui Peradilan Umum atau Badan Penyelesaian Sengketa Konsumen (BPSK).

Bahkan menurut drg. Joko Supriyanto, M.Hum ${ }^{15}$ selaku dokter di Lapas Narkotika Klas IIA Yogyakarta bahwa dalam penyelesaian sengketa medis jalur mediasi merupakan alat penyelesaian sengketa medis antara dokter dengan pasien yang tepat dimana melalui mediasi dapat diselenggarakan perundingan atau musyawarah untuk mencapai mufakat dengan bantuan pihak ketiga yang netral dan tidak memiliki kewenangan untuk memutus sangat diperlukan.

\section{KESIMPULAN}

Praktik kedokteran menurut UndangUndang Nomor Nomor 29 tahun 2004 tentang Praktik Kedokteran diselenggarakan berdasarkan pada kesepakatan antara dokter atau dokter gigi dengan pasien dalam upaya untuk pemeliharaan kesehatan, pencegahan penyakit, peningkatan kesehatan, pengobatan penyakit dan pemulihan kesehatan. Kesepakatan ini dilaksanakan berdasarkan kepercayaan disebut perjanjian terapautik.

Terjaminnya kepercayaan dapat dipenuhi dengan penyesuaian penyelenggaraan
Perjanjian Terapeutik dengan aspek hukum perdata sebagai ketentuan yang mengatur hak dan kepentingan antar individu dalam masyarakat. Untuk sahnya suatu Perjanjian Terapeutik mengacu pada Pasal 1320 KUHPdt yakni sebagai berikut:

1. Kesepakatan mereka yang mengikatkan dirinya (toestetning van degenen die zich verbinden);

2. Kecakapan untuk membuat suatu perikatan (de bekwaamheid om eene verbintenis aan te gaan);

3. Suatu pokok persoalan tertentu (een bepaald onderwerp);

4. Suatu sebab yang tidak terlarang (eene geoorloofdeoorzaak).

Unsur-unsur tersebut dapat dilihat dari adanya informed consent sebagai rincian tindakan medis yang akan ditempuh oleh pasien yang ditandatangangi oleh pasien atau wali yang cakap secara hukum. informed consent merupakan perlindungan hukum bagi pasien dan dokter, dalam artian bagi dokter menjadi pembenar/legalitas/keabsahan dari tindakan medis yang ditempuh sesuai persertujuan, sedangkan bagi pasien informed consent berguna untuk memberikan gambaran apakah tindakan medis yang diterima sesuai dengan kebutuhan.

Guna mengoptimalkan tujuan dari penyelenggaraan perjanjian terapeutik perlu

15 Agung, (10 Agustus 2015), Konflik Dokter dan Pasien Wajib Gunakan Mediasi, Diakses pada tanggal 7 April 2020, Dari Universitas Gadjah Mada: https://ugm.ac.id/id/berita/10262-konflik-dokter-dan-pasien-wajibgunakan-mediasi. 
diperhatikan penerapan asas proporsionalitas, dalam pelaksanaan perjanjian terpautik diperlukan keterbukaan informasi sehingga meski pada mulanya pasien dan dokter memiliki ketidaksetaraan posisi dikarenakan pengetahuan yang dimiliki dapat menjadi setara sehingga pasien kemudian diberikan kebebasan untuk dapat menentukan tindakan medis apa yang akan ditempuh.

Sejatinya, ukuran proporsionalitas pertukaran hak dan kewajiban didasarkan pada nilai-nilai kesetaraan (equitability), kebebasan, distribusi-proporsional, tentunya juga tidak dapat dilepaskan dari asas atau prinsip kecermatan (zorgvuldigheid), kelayakan (redelijkheid; reasonableness) dan kepatutan (billijkheid; equity). Namun perlu dipahami ukuran ini bukan dalam sifat matematis meskidemikian fungsi dari asas proporsionalitas dapat dilihat sebagaimana penerapannya dalam penjanjian umumnya dimana terbukanya peluang negosiasi, kesetaraan hak serta kebebasan dalam menentukan/mengatur proporsi hak dan kewajiban para pihak, dan apabila bersengketa pun masing-masing pihak memiliki alur serta posisi yang sama dapat ditempuh

\section{DAFTAR PUSTAKA}

\section{Peraturan Perundang-Undangan}

Undang-Undang Dasar Negara Republik Indonesia Tahun 1945

Undang-Undang Nomor 44 Tahun 2009 tentang Rumah Sakit
Undang-Undang Nomor 36 Tahun 2009 tentang Kesehatan

Undang-Undang Nomor 29 Tahun 2004 tentang Praktik Kedokteran

Peraturan Menterian Kesehatan Republik Indonesia Nomor 290/MENKES/PER/III/ 2008 tentang perjanjian tindakan medis

Kitab Undang-Undang Hukum Perdata

\section{Jurnal}

Evy Savitri Gani, (_, Desember 2018), Tinjauan Yuridis Kedudukan Hukum Para Pihak Dalam Perjanjian Terapeutik, Tahkim: Jurnal Hukum dan Syariah, Volume XIV, Nomor 2.

(12 September 2011), Gerbang untuk Memahami Hukum Perdata Indonesia, Diakses pada tanggal 1 April 2020, Dari Hukum Online: https://www.hukumonline.com/berita/b aca/lt4e6da6a1b9b56/gerbang-untukmemahami-hukum-perdata-indonesia/

Achmad Busro, (9 November 2018), Aspek Hukum Persetujuan Tindakan Medis (Inform Consent) dalam Pelayanan Kesehatan, Law, Development \& Justice Review, Volume 1, Nomor 1.

Agus Yudha Hernoko, “Asas Proporsionalitas sebagai Landasan Pertukaran Hak dan Kewajiban Para Pihak Dalam Kontrak Komersial", Disertasi Universitas Airlangga, 2007.

Bayu Winarko dan Mudiana Permata Sari, (_, _ _ _ _), Tinjauan Yuridis Sahnya Perjanjian Terapeutik dan Perlindungan Hukum Bagi Pasien, Private Law, Volume __, Nomor

Budi Sampurna, (_, _ , 2001), Wewenang dan Tanggungjawab Daripada Tindakan Bedah Kulis Kosmetik, Majalah Kedokteran Indonesia, Volume 11, Nomor 11.

Yovita Arie Mangesti dan Azmi Syahputra, (_, _ , 2019), Elaborasi Nilai Pancasila pada Perjanjian Terapeutik 
dalam Rangka Pembaharuan Hukum Kesehatan, Jurnal Jurisprudence, Volume 9, Nomor 1.

\section{Internet}

(22 Juli 2017), Kontrak Abaikan

Asas Proporsionalitas Dapat Dibatalkan, Diakses pada tanggal 24 Februari 2020, Dari Litigasi: https://litigasi.co.id/kontrakabaikan-asas-proporsionalitas-dapatdibatalkan.

Agung, (10 Agustus 2015), Konflik Dokter dan Pasien Wajib Gunakan Mediasi, Diakses pada tanggal 7 April 2020, Dari Universitas Gadjah Mada: https://ugm.ac.id/id/berita/10262konflik-dokter-dan-pasien-wajibgunakan-mediasi.
Safitri Hariyani Saptogino, (14 Maret 2019), Penyelesaian Sengketa Medik di Indonesia, Diakses pada tanggal 7 April 2020, Dari Sip Law Firm: https://siplawfirm.id/penyelesaiansengketa-medik-di-indonesia/?lang=id.

Xavier Nugraha, (16 Mei 2019), Asas Proporsionalitas Sebagai Solusi Terciptanya Kontrak yang Saling Menguntungkan Para Pihak, Diakses pada tanggal 2 April 2020, Dari Unair News:

http://news.unair.ac.id/2019/05/16/asasproporsionalitas-sebagai-solusiterciptanya-kontrak-yang-salingmenguntungkan-para-pihak/. 